Tetiana Bilushchak,

Ph.D. in History, Assistant Lecturer,

Lviv Polytechnic National University, 3, Mytropolyta Andreya St., Lviv, 79013, Ukraine,

ORCID: 0000-0001-5308-1674

ResearcherID: R-1524-2017

\title{
VIRTUAL EXHIBITION ACTIVITIES OF DOCUMENTARY AND INFORMATION INSTITUTIONS OF LVIV AS A TOOL FOR PROMOTION AND DEVELOPMENT OF CULTURAL TOURISM
}

We have considered the role of libraries and archives in the development and promotion of cultural tourism in Lviv. With the help of the analytical tools for collecting statistics Google Trends, the level of population's interest in information about Lviv and interest in the documentary and information institutions on the Internet has been determined based on the search queries. There have been surges in interest at certain time intervals, both in Ukraine and abroad. Based on the results of statistics as regards the interest in information about the documentary and information institutions of Lviv, virtual exhibition activities of such institutions as a tool used to promote the development of the tourist industry of the city have been substantiated. The general characteristics of the strengths, weaknesses, opportunities and threats to promotion of cultural tourism in Lviv through the virtual exhibition activities of the documentary and information institutions using the method of SWOT analysis have been analyzed. By means of the tools of structured modeling of business processes, namely the activity diagram using the additional Swimlane component, the process of creating virtual exhibition activities of the documentary and information institutions for the promotion of cultural tourism in Lviv has been presented and the applications for its implementation have been proposed.

Keywords: virtual exhibition activities, cultural tourism, information resource, library, archive.

Relevance of research topic. In the context of the European integration processes, tourism is a strategic socio-cultural factor for Ukraine's development. A powerful driver in the development of tourism becomes the historical and cultural heritage, where cultural area gains an advantage.

The relevance of the paper topic is that the integrative processes taking place in the system of electronic communications and the development of promotion of the historical and cultural heritage change the terms of cooperation between the documentary and information institutions and the tourism industry in respect of the 
promising directions of work. In these settings, the issue of virtual exhibition activities of libraries and archival institutions, which hold the huge funds of historical and cultural heritage as a tool for promotion and development of cultural tourism, becomes trending. Thus, functioning of virtual exhibitions with the cooperation between the documentary and information institutions and the tourism industry will enhance the desire to visit interesting places and see everything with your own eyes, thus informing and inspiring to a real trip.

Formulation of the problem. Despite the challenging situation in the country, our time is a period of the development of new trends in cultural life, previously forgotten names, monuments and events are reviving, the historical heritage is reevaluated. Therefore, the focus on cultural tourism is a possibility of economic, social and cultural rise for Lviv and Lviv region.

Lviv has always been considered the most famous and the largest tourist center of Western Ukraine, and according to the official statistics from Euromonitor International in 2018, Lviv leads and has dominant positions among not only the cities of Ukraine, but also Europe and the world. Given the city's rich history, it has unique historical, cultural and recreational resources. The developed tourist infrastructure and an advantageous location add to the tourism appeal.

The term «cultural tourism» was for the first time formally used internationally in the proceedings of the World Conference on Cultural Policies. UNESCO considers cultural tourism to be a different kind of tourism, «taking into account the cultures of other peoples». As evidenced by the experience of the European countries the development of cultural tourism plays an important role in the documentary and communication structures such as libraries and archives. Therefore, this poses a challenge to study the segment of involvement of the documentary and information institutions in the development of cultural tourism with the help of the state-of-the-art information and communication technology, in particular, in the form of the virtual exhibition activities that will promote the development of tourism business in Lviv in general.

Based on the above, we can formulate the research objective, which is to determine the interest of the Internet users in the cultural and tourist sites of Lviv, to systematize the range of problems and the benefits of the development of cultural tourism in Lviv with the help of virtual exhibitions of library and archival holdings for promotion of cultural and historical heritage using the method of SWOT analysis, as well as to formalize the process of displaying virtual exhibition activities of the documentary and information institutions to promote cultural tourism in Lviv using Swimlane activity diagram. The aim of the research is to substantiate the feasibility of developing virtual exhibition activities by the documentary-information institutions of Lviv in order to promote the historical and cultural heritage and the ways of their implementation in the development of cultural tourism, as well as to find out the role of libraries and archives as components of the tourist space. 
Analysis of recent researches and publications. The investment attractiveness of the Ukrainian tourist system [1-3,6], the tendencies and prospects of the development of virtual exhibitions as a promotion of historical and cultural heritage $[4,8,11]$ and the benefits of the development of cultural tourism in Ukraine [12-13] are widely studied by the Ukrainian scholars. To research this topic, they also studied the experiences of foreign colleagues, where they analyze the role of libraries as cultural and information institutions that can make a significant contribution to the development of cultural tourism, in particular, the models of numerous strategic issues of public libraries for tourist destinations have been considered [5, 7, 9-10].

Presenting main material. Modern tourism in the context of globalization processes is gaining new directions and development. The integration of libraries, museums and archives into tourism is a promising and innovative area of work. Taking into account the conditions of development of the information society, the tendencies of updating the cultural potential of tourism, people pay more attention to the promotion of their activities on the Internet. An important element of the effectiveness of the above is the compatibility of search queries of the target audience with the content, in particular, a set of keywords used there. In order to determine the interest of the Internet users, we have conducted a search query analysis using Google Trends. Queries were generated using the entered criterion - «for the last 12 months», «Search on Web» (Table 1).

Table 1

\section{Popular search query analysis}

\begin{tabular}{|l|c|c|c|c|}
\hline \multicolumn{1}{|c|}{ Term } & $\begin{array}{c}\text { Period of the } \\
\text { highest interest }\end{array}$ & $\begin{array}{c}\text { Period of the } \\
\text { lowest interest }\end{array}$ & $\begin{array}{c}\text { Interest by } \\
\text { regions/cities, } \\
\text { countries }\end{array}$ & $\begin{array}{c}\text { Related search } \\
\text { queries }\end{array}$ \\
\hline $\begin{array}{l}\text { Historical Center } \\
\text { of Lviv } \\
\text { (Istorychnyi } \\
\text { tsentr Lvova) }\end{array}$ & $\begin{array}{c}29.12 .2019- \\
04.01 .2020\end{array}$ & $22.03-28.03 .2020$ & $\begin{array}{c}\text { Ukraine (Lviv, } \\
\text { Ternopil, Kyiv, } \\
\text { Odesa regions), } \\
\text { Belarus, } \\
\text { Poland, the USA }\end{array}$ & $\begin{array}{c}\text { Hotel Lviv } \\
\text { Center, Lviv } \\
\text { Center. (Hotel } \\
\text { Lviv Tsentr } \\
\text { Tsentr Lvova) }\end{array}$ \\
\hline $\begin{array}{l}\text { Vasyl Stefanyk } \\
\text { Lviv National } \\
\begin{array}{l}\text { Scientific Library } \\
\text { of Ukraine } \\
\text { (Lvivska }\end{array}\end{array}$ & $08.12-14.12 .2019$ & $22.03-28.03 .2020$ & Lviv region, Kyiv \\
$\begin{array}{l}\text { Natsionalna } \\
\text { Naukova }\end{array}$ & & & $\begin{array}{c}\text { Ukraine. (Lviv - } \\
\text { misto v Ukraini) }\end{array}$ \\
$\begin{array}{l}\text { Biblioteka Ukrainy } \\
\text { Im. V. Stefanyka) }\end{array}$ & & & & \\
\hline
\end{tabular}




\begin{tabular}{|l|c|c|c|c|}
\hline \multicolumn{1}{|c|}{ Term } & $\begin{array}{c}\text { Period of the } \\
\text { highest interest }\end{array}$ & $\begin{array}{c}\text { Period of the } \\
\text { lowest interest }\end{array}$ & $\begin{array}{c}\text { Interest by } \\
\text { regions/cities, } \\
\text { countries }\end{array}$ & $\begin{array}{c}\text { Related search } \\
\text { queries }\end{array}$ \\
\hline $\begin{array}{l}\text { State archive of } \\
\text { Lviv region } \\
\text { (Derzhavnyi } \\
\text { Arkhiv Lvivskoi } \\
\text { Oblasti) }\end{array}$ & $14.04-20.04 .2019$ & $08.03-14.03 .2020$ & Lviv region & $\begin{array}{l}\text { Lviv - a city in } \\
\text { Ukraine. (Lviv - } \\
\text { misto v Ukraini) }\end{array}$ \\
\hline $\begin{array}{l}\text { National } \\
\text { Museum in Lviv } \\
\text { (Natsionalnyi } \\
\text { muzei u Lvovi) }\end{array}$ & $13.10-19.10 .2019$ & $16.02-22.02 .2020$ & Lviv region, Kiev & $\begin{array}{l}\text { Lviv - a city in } \\
\text { Ukraine. (Lviv - } \\
\text { misto v Ukraini) }\end{array}$ \\
\hline
\end{tabular}
Trends

Source: The analysis search query popularity was conducted by the author using Google

The statistics generated by Google Trends show us the periods of the highest and the lowest interest, as well as the dynamics of query generation in the time interval, tracking the activities of query creation in certain places of Ukraine and abroad. Based on the data obtained, where we observe the dynamics of the periods of interest, we can conclude that the issue of searching for information in the documentary and information institutions of Lviv is topical for the Internet users.

The promotion of historical and cultural heritage in Lviv in the field of virtual tourism on the basis of museum exhibitions is more developed, than, for example, of libraries and archives. The Department of Culture, Nationalities and Religions of the Lviv Regional State Administration launched a new interactive museum project «Visit» («Vidvidai») http://old.dailylviv.com/3D/loda/ in 2018, where you can enjoy museum exhibits of Lviv and Lviv region in the virtual exhibition space, thereby exciting the curiosity and encouraging people to visit them in person. Therefore, the priority direction for improving (expanding) the development of cultural tourism is the development of promotional and information resources for libraries and archival institutions in the form of virtual exhibitions, which could be of interest and thus increase the tourist traffic to the city.

Lviv is a unique city that has been absorbing the history and culture of different epochs and peoples for many centuries. Considering the uniqueness of the city, library holdings and archival funds, with the help of which virtual exhibitions will be created, are perspective. This will make it possible for the potential tourists to visit places and choose for themselves the most interesting objects that are connected, in particular, with medieval Lviv, architectural, literary, musical city and Lviv related to the historical figures. Thus, the potential for cultural tourism is revealed through virtual exhibitions, and given the history of the city - of military and historical tourism as well.

In order to systematize the range of issues and benefits of the development of cultural tourism in Lviv with the help of virtual exhibitions of library holdings and 
archival funds for the promotion of cultural and historical heritage, it is necessary to conduct a SWOT analysis of the status of this type of activities. It is also possible to identify the priorities for the development of cultural tourism, to create new concepts and plans using the SWOT analysis. Thus, SWOT analysis has been used to identify and address the existing weaknesses and develop recommendations for enhancing the level of cultural tourism development in Lviv (Table 2).

Table 2

\section{SWOT analysis of cultural tourism promotion in Lviv with the help of virtual exhibition activities of documentary and information institutions}

\begin{tabular}{|c|c|}
\hline Strengths & Weaknesses \\
\hline $\begin{array}{l}\text { 1. The oldest part of the old city is included in the } \\
\text { UNESCO World Heritage List. } \\
\text { 2. Potential for military-historical tourism, ethnic, } \\
\text { religious, gastronomic and other types of tourism. } \\
\text { 3. The Unique Metropolitan Andrey Sheptytsky } \\
\text { Center and the innovative library of the } \\
\text { Ukrainian Catholic University, which has no } \\
\text { analogues in Ukraine. } \\
\text { 4. A sufficient number of museums and memorial } \\
\text { sites. } \\
\text { 5. Functioning of «!FEST» Holding of Emotions - } \\
\text { a chain of creative restaurants and projects with } \\
\text { original concepts («Kryivka», «Masoch-café», } \\
\text { «Lviv Coffee Mine», «Under Arsenal») } \\
\text { 6. Favorable economic and geographical location } \\
\text { on the border with the EU, availability of border } \\
\text { crossing points. } \\
\text { 7. Availability of natural and recreational resources }\end{array}$ & $\begin{array}{l}\text { 1. Environmental problems (landfills } \\
\text { in Lviv). } \\
\text { 2. Poor quality of roads } \\
\text { 3. Absence of top class hotels } \\
\text { 4. High level of prices for domestic tourists } \\
\text { 5. Inadequate support and underfunding of } \\
\text { most sites of historical and architectural } \\
\text { heritage }\end{array}$ \\
\hline Opportunities & Threats \\
\hline $\begin{array}{l}\text { 1. Possibility of positioning the city as a reading } \\
\text { capital, etc. } \\
\text { 2. Establishment of cooperation of information } \\
\text { resources of libraries and archives with tourist } \\
\text { resources. } \\
\text { 3. Participation in international tourist exhibitions } \\
\text { 4. Development of new tourist markets. } \\
\text { 5. Availability of investment projects for the } \\
\text { development of recreation areas. } \\
\text { 6. Possibility of growth of the tourist services } \\
\text { market with the efficient use of available tourist } \\
\text { resources and infrastructure. } \\
\text { 7. Growing interest of citizens in the historical and } \\
\text { cultural heritage }\end{array}$ & $\begin{array}{l}\text { 1. Political instability in the state } \\
\text { 2. Low income of Ukrainian citizens } \\
\text { 3. Rapid development of competing cities }\end{array}$ \\
\hline
\end{tabular}

Source: Developed by the author 
Conducting SWOT analysis also gives an opportunity to identify territorial features and current trends of the cultural tourism development in Lviv. The SWOT analysis made it possible to evaluate in an unbiased manner the weaknesses and threats of the development and promotion of cultural tourism in the city through virtual exhibition activities. According to the analysis of the strengths, designing virtual exhibitions for the promotion of cultural tourism in Lviv gives grounds to identify the potential of the city and develop an effective strategy for their further strengthening.

We used the Swimlane activity diagram, which is shown in Figure 1, to formalize the process of displaying virtual exhibition activities of the documentary and information institutions for the promotion of cultural tourism in Lviv.

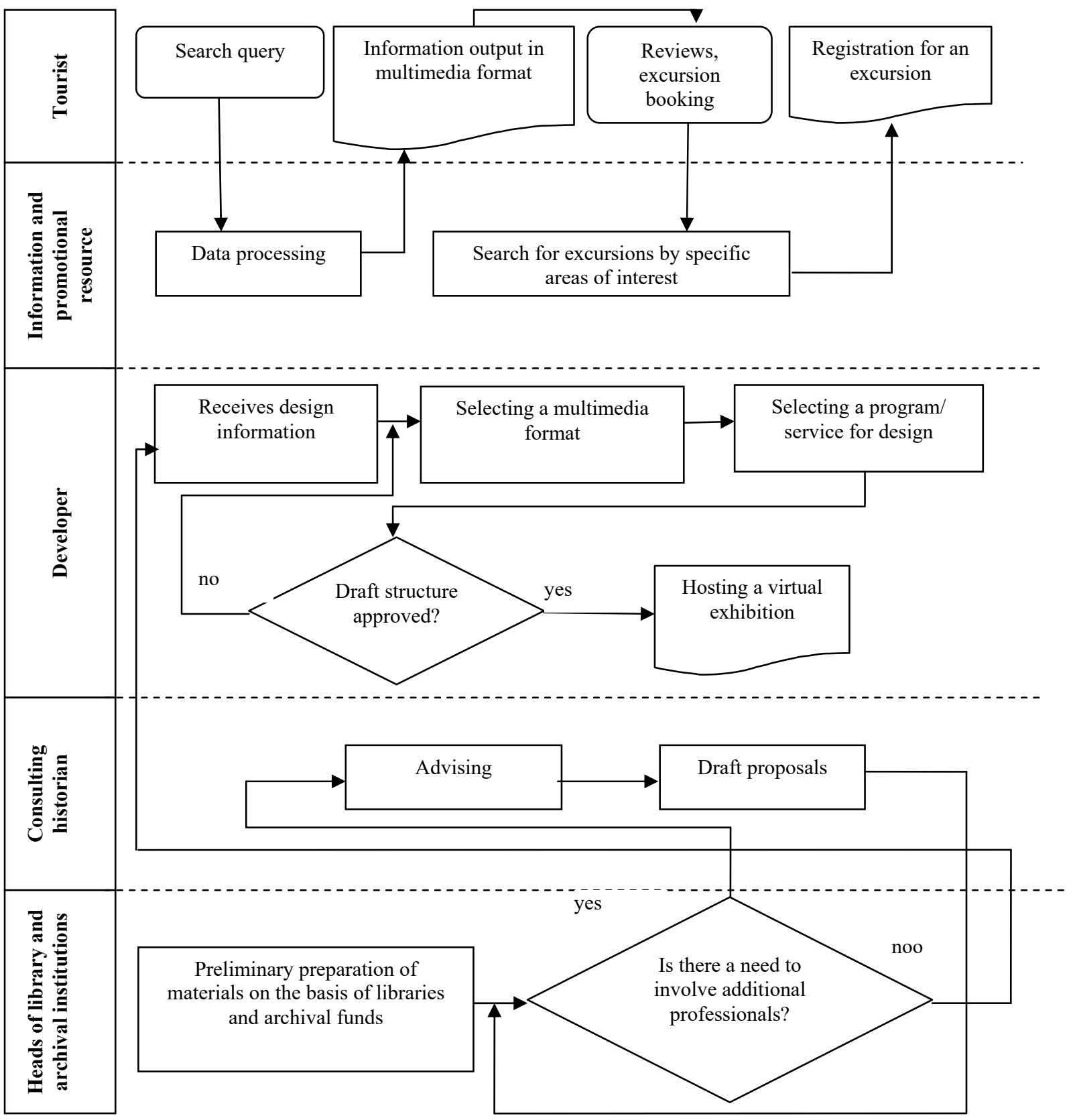

Fig.1. Using the activity diagram of the process of creating virtual exhibition activities of the documentary and information institutions for the promotion of cultural tourism in Lviv Source: Developed by the author 
Activity diagrams are used to show the sequence of actions when modeling business processes. This notation is used to represent the algorithm (script) of the process. An additional diagram component called Swimlane has been used for this modeling and research.

Swimlane are visually separated lines within a process diagram that group actions by roles, resources, organization elements, or locations. Swimlane visualizes actions that are carried out by specific types of resources, roles, or elements of the organization or that are associated with a specific place. What is more, the roles of the works performers can be indicated on the Swimlane diagrams, and thus one can better document the responsibilities of the performers.

Figure 1 shows a graphic model of the interaction between the developer, heads of libraries and archives, consulting historians and potential tourists in the information and promotional resource using the activity diagram. Each stage in the model can be detailed to the required level of concretization. Let us consider the details in the algorithm of choosing the multimedia format and the application for implementation in Figure 2 .

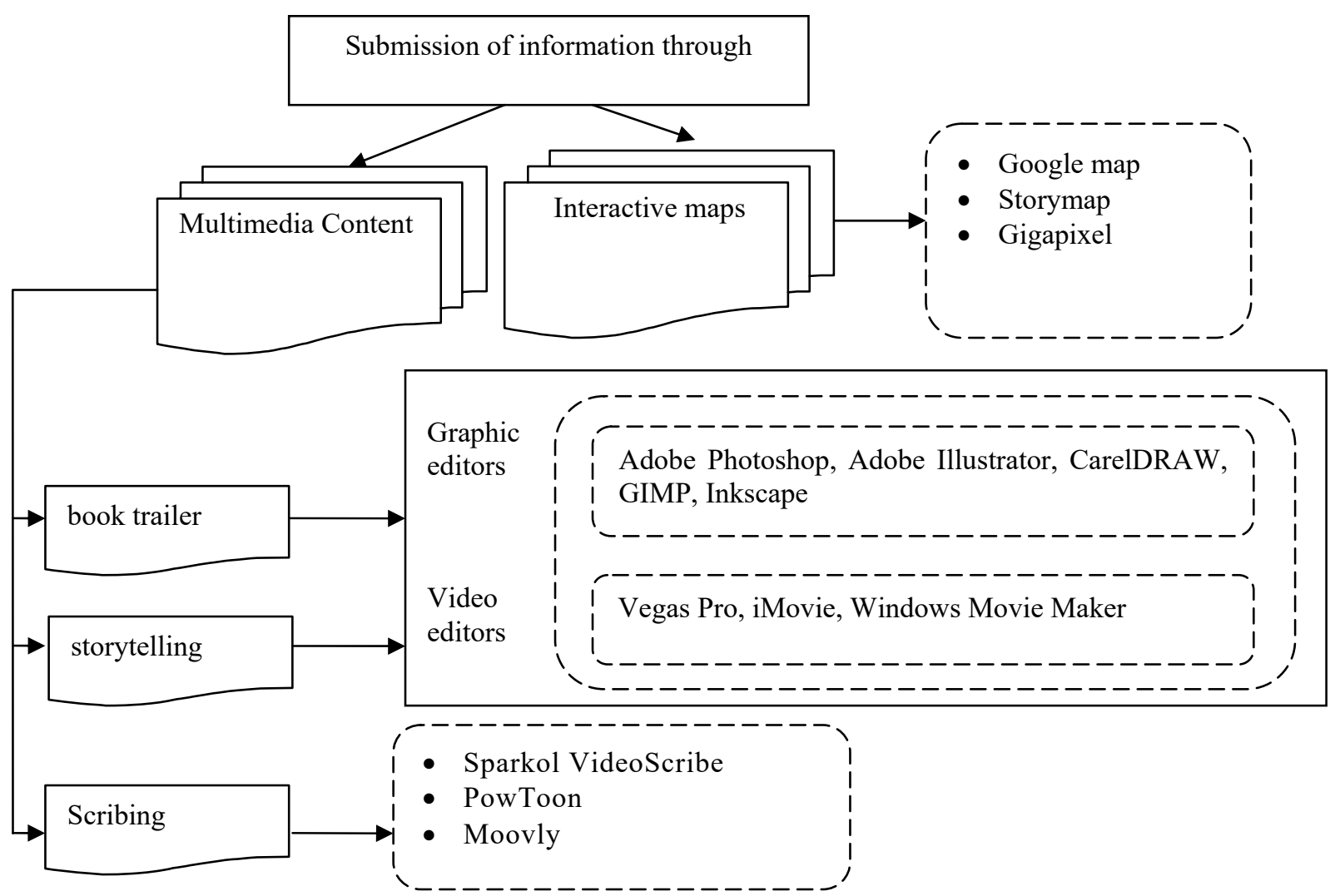

Fig. 2. Detailing the algorithm of choosing the multimedia format of information and its implementation

Source: Developed by the author 
To make potential tourists interested in visiting the historical sites of Lviv, it has been suggested to present information and its implementation through multimedia content such as book trailers, storytelling and scribing, as well as through interactive maps, where you can place videos, photos and text information.

Conclusion. Thus, on the basis of the conducted research, we have found out the level of interest on the Internet to the documentary and information institutions and information about Lviv with the help of the analytical tools for collecting statistics of Google Trends service. Based on the results of information interest statistics and the level of web search, the general characteristics of strengths, weaknesses, opportunities and threats of cultural tourism promotion in Lviv have been analyzed by means of virtual exhibition activities of the documentary and information institutions using the method of SWOT analysis. In addition, through the means of structured modeling of business processes, namely the activity diagram using the additional Swimlane component, virtual exhibition activities of the documentary and information institutions with regard to the promotion of cultural tourism in Lviv have been displayed and the applications and approaches for its implementation have been suggested.

Thus, the process of interaction between the tourism industry and the documentary and information institutions, namely the organization of virtual exhibitions on the basis of library holdings and archival funds on various topics of Lviv will allow to address several important tasks for the local community - meet the needs of the population for leisure and recreation, which will promote tourism business development and attraction of investments in the development of the region, etc. The directions of penetration of the tourism industry in the activities of libraries will make it possible to create and develop various tourist routes, including interactive ones, based on archival and library studies; provide tourists with reference and information services in the tourism sector, either directly in the library or in the archive, or online; organize online discussions and groups on social networks to discuss the history of the city, the development of various types of tourism, namely military-historical, ethnic, religious, gastronomic and other types of tourism. Creating websites and blogs that represent the tourist appeal of Lviv, etc.; cooperation with travel companies on initiation of the new tourist itineraries and assisting tour guides in the content of excursions; assistance in providing meaningful recreation and creating recreational and leisure areas in city libraries, such as the unique library of Ukraine the Library of the Ukrainian Catholic University and the A. Sheptytsky Center.

\section{REFERENCES}

1. Boiko, M., Bosovska, M., Vedmid, N., Bovsh, L. \& Okhrimenko, A. (2018). Investment attractiveness of the Ukrainian tourism system. Investment Management and Financial Innovations, 15(4), 193-209. DOI: 10.21511/imfi.15(4).2018.16.

2. Boiko, M., Bosovska, M., Vedmid, N., Melnychenko, S. \& Okhrimenko, A. (2017). Development of the tourism cluster. Problems and Perspectives in Management (open-access), 15(4), 134-149. DOI:10.21511/ppm.15(4).2017.12. 
3. Boiko, M., Vedmid, N., Okhrimenko, A. (2017). The crowdfunding technology in development of the national tourism system. Financial and credit activity: problems of theory and practice, [S.1.], v. 2, n. 23, 91-100. DOI: http://dx.doi.org/10.18371/fcaptp.v2i23.121318.

4. Dobrovolska, V., Myna, Zh., Bilushchak T. (2019). Information research resources of the historical and cultural sphere on the Internet. National Academy of Managerial Staff of Culture and Arts Herald, № 2, 365-370.

5. Karuza, I., Krajnović, A., \& Volić, I. (2017). The Public Library Strategic Orientation in Tourist Destination: Managing the Complexity of Community and Tourism Orientation. Retrieved from https://www.westeastinstitute.com/wpcontent/uploads/2017/02/Irina-Karuza-Aleksandra-Krajnovic-Ivona-MikulandraVolic.pdf

6. Mazaraki, A., Boyko, M., Bosovska, M., Vedmid, N. \& Okhrimenko, A. (2018). Formation of the national tourism system of Ukraine. Problems and Perspectives in Management (open-access), 16(1), 68-84. DOI: 10.21511/ppm.16(1).2018.07.

7. Moiteiro, G. (2017). What if Documentary Heritage Attracted Tourists? Thoughts on the Potential for Tourism of Historical Libraries and Archives. Tourism and History World Heritage - Case Studies of Ibero-American Space, 568-584.

8. Myna, Zh., Bilushchak, T., Melnyk, R. (2019). Exhibition and exposition activity using advanced information and advertising tools as a powerful way to popularize cultural values of the state. Problem space of modern society: philosophical-communicative and pedagogical interpretations: collective monograph. Part I., Warsaw, 602-618.

9. Seifi, L., \& Kazemi, R. (2019). The Role of Iran Public Libraries in Development and Promoting of Tourism Services. Retrieved from https://digitalcommons.unl.edu/ libphilprac/2953/.

10. Yang, L., Xiaodong, L. (2019). «Library + Tourism»: A New Direction for the Sustainable Development of Libraries. Retrieved from http://ibrary.ifla.org/2703/ 1/S09-2019-li-en.pdf.

11. Білущак, Т., Акиджи, В. (2019). Особливості сервісів для створення віртуальних виставок у формуванні ефективного бібліотечно-інформаційного простору. Вісник Книжккової Палати, № 2, 45-48.

12. Дорофєєва, Х. (2017). Аналіз впливу наявності об'єктів культурноісторичної спадщини на туристичну привабливість регіону. Економіка та суспільство, Вип.13, 184-190.

13. Музиченко-Козловська, О. (2015). Теоретико-методичні засади туристичного брендингу міста (на прикладі м. Львова). Вісник Національного університету «Львівська політехніка». Менеджмент та підприємництво в Україні: етапи становлення і проблеми розвитку, № 835, 63-70. 